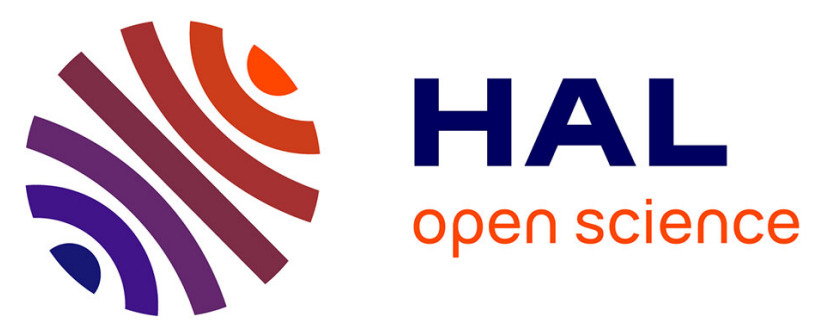

\title{
Al2O3 thin films deposited by thermal atomic layer deposition: Characterization for photovoltaic applications
}

Corina Barbos, Danièle Blanc-Pélissier, Alain Fave, Claude Botella, Philippe Regreny, Geneviève Grenet, Elisabeth Blanquet, Alexandre Crisci, Mustapha

Lemiti

\section{To cite this version:}

Corina Barbos, Danièle Blanc-Pélissier, Alain Fave, Claude Botella, Philippe Regreny, et al.. Al2O3 thin films deposited by thermal atomic layer deposition: Characterization for photovoltaic applications. Thin Solid Films, 2016, 617 (Part B), pp.108-113. 10.1016/j.tsf.2016.02.049 . hal-01712453

\section{HAL Id: hal-01712453 \\ https://hal.science/hal-01712453}

Submitted on 19 Feb 2018

HAL is a multi-disciplinary open access archive for the deposit and dissemination of scientific research documents, whether they are published or not. The documents may come from teaching and research institutions in France or abroad, or from public or private research centers.
L'archive ouverte pluridisciplinaire HAL, est destinée au dépôt et à la diffusion de documents scientifiques de niveau recherche, publiés ou non, émanant des établissements d'enseignement et de recherche français ou étrangers, des laboratoires publics ou privés. 


\title{
$\mathrm{Al}_{2} \mathrm{O}_{3}$ thin films deposited by thermal Atomic Layer Deposition: characterization for photovoltaic applications
}

\author{
Corina Barbos ${ }^{\mathrm{a}}$, Danièle Blanc-Pelissier ${ }^{\mathrm{a}}$, Alain Fave ${ }^{\mathrm{a}}$, Elisabeth Blanquet ${ }^{\mathrm{b}}$, \\ Alexandre Crisci ${ }^{\mathrm{b}}$, Mustapha Lemiti ${ }^{\mathrm{a}}$
}

\author{
${ }^{a}$ Université de Lyon ; Institut des Nanotechnologies de Lyon INL - UMR5270, CNRS ; INSA Lyon ; Villeurbanne, \\ F-69621, France \\ ${ }^{b}$ Science et Ingénierie des Matériaux et Procédés (SIMaP), F-38 402, St Martin d'Heres, France

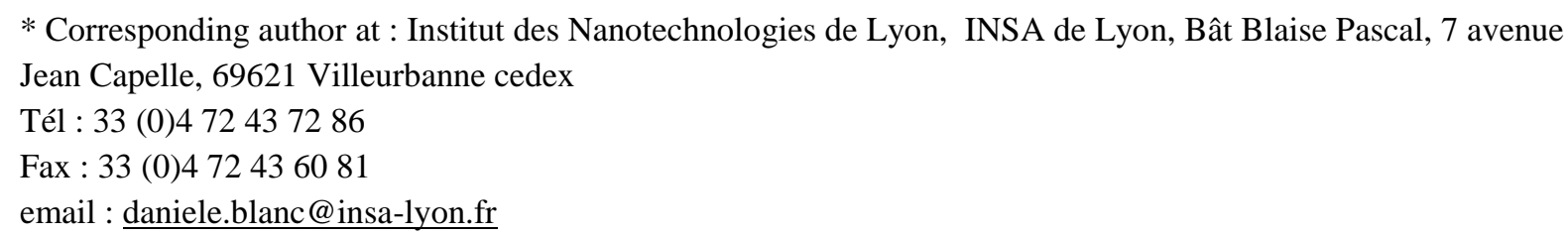

Keywords: $\mathrm{Al}_{2} \mathrm{O}_{3}$; Atomic layer deposition; Thin films; Interface characterization; Surface passivation.

\begin{abstract}
$\mathrm{Al}_{2} \mathrm{O}_{3}$ thin films with thickness between 2 and $100 \mathrm{~nm}$ were synthetized at $250^{\circ} \mathrm{C}$ by thermal atomic layer deposition on silicon substrates. Characterizations of as-deposited and annealed layers were carried out using ellipsometry, X-ray reflectivity and X-ray photoelectron spectroscopy. A silicon-rich $\mathrm{SiO}_{x}$ layer at the interface between $\mathrm{Si}$ and $\mathrm{Al}_{2} \mathrm{O}_{3}$ was introduced in the optical models to fit the experimental data. Surface passivation performances of $\mathrm{Al}_{2} \mathrm{O}_{3}$ layers deposited on n-type float-zone monocrystalline silicon were investigated as a function of thickness and post-deposition annealing conditions. Surface recombination velocity around $2 \mathrm{~cm} . \mathrm{s}^{-1}$ was measured after the activation of the negative charges at the $\mathrm{Si} / \mathrm{Al}_{2} \mathrm{O}_{3}$ interface under optimized annealing at $400^{\circ} \mathrm{C}$ for $10 \mathrm{~min}$. The evolution of the interface layer and of the material properties with the thermal treatment was studied.
\end{abstract}

\section{Introduction}

Passivation of silicon surfaces is essential to achieve high solar cell performances. Several trends in photovoltaics have played an important role in the popularity of $\mathrm{Al}_{2} \mathrm{O}_{3}$ for efficient surface passivation. Firstly, the photovoltaic (PV) industry has been looking to improve the rear side of conventional screen printed p-type Si solar cells by replacing the standard Al-back surface field (BSF) by a dielectric-passivated rear side with localized BSF. Secondly, the use of n-type Si which does not suffer from light induced degradation and is less sensitive to common metal impurities, has become an attractive option for the fabrication of high solar cell efficiencies. The high density of negative charges in $\mathrm{Al}_{2} \mathrm{O}_{3}$ is well suited for the passivation of $p+$ emitters on n-type substrate [1]. A very high conversion efficiency of $23.9 \%$ for an n-type Passivated Emitter Rear Locally Diffused PER $L$ solar cell with a front side Bdoped emitter and an $\mathrm{Al}_{2} \mathrm{O}_{3}$ passivation layer has been reported [2,3]. Recent works [4, 5] 
have demonstrated that $\mathrm{Al}_{2} \mathrm{O}_{3}$ could also be efficient for passivation of n-type silicon substrates.

Along with $\mathrm{Al}_{2} \mathrm{O}_{3}$, atomic layer deposition (ALD) was introduced in the field of Si PV. ALD differs from conventional (plasma enhanced) chemical vapor deposition methods by strict separation of precursors in the reaction chamber. As the precursors can only react with the wafer surface in a self-limiting way, film growth proceeds layer-by-layer and a very precise thickness control is possible. This technique is ideal for depositing high quality, uniform and conformal thin films at relatively low temperatures $\left(100-250{ }^{\circ} \mathrm{C}\right)$. The passivation of high aspect ratio surface texturation (nanowires, "black silicon"), used to improve the optical confinement in advanced solar cells, requires a very conformal thin passivation layer. $\mathrm{Al}_{2} \mathrm{O}_{3}$ deposited by thermal ALD (more conformal than plasma enhanced ALD) becomes the ideal candidate for this passivation layers.

Given the multiple advantages of $\mathrm{Al}_{2} \mathrm{O}_{3}$ deposited by $\mathrm{ALD}$, this material has become widely used for photovoltaic applications [6] where the commonly used thickness is less than $15 \mathrm{~nm}$. Therefore, an important need in very thin film characterization has appeared. However, very thin films $(<10 \mathrm{~nm})$ are difficult to characterize precisely as interfaces play a major role in the data analysis. For example, thickness and refractive index are difficult to measure separately by optical techniques like ellipsometry as they are highly correlated [7]. Consequently various characterizations techniques and optical models should be used and compared in order to determine very thin film properties.

In this study, $\mathrm{Al}_{2} \mathrm{O}_{3}$ layers with thicknesses in the range 2 to $100 \mathrm{~nm}$ were deposited by thermal-ALD on n-type crystalline $\mathrm{Si}$ substrates. Fast, non-destructive and accurate characterization techniques were chosen to analyze the $\mathrm{Al}_{2} \mathrm{O}_{3}$ layers and the interfaces. Optical and geometrical properties of the $\mathrm{Al}_{2} \mathrm{O}_{3}$ layers were studied by ellipsometry and X-ray reflectivity (XRR). Stoichiometry was measured by X-ray photoelectron spectroscopy (XPS) to analyze the material and the interface structure. The surface passivation of the Si wafers was evaluated by photo-conductance measurements. Characterization of the $\mathrm{Al}_{2} \mathrm{O}_{3}$ layers and of the interfaces was performed before and after the thermal treatment that is required to improve the surface passivation of silicon.

\section{Sample preparation}

We used $250 \mu \mathrm{m}$ thick float zone (FZ) n-type double sided polished Si (100) substrates with a resistivity of $10 \Omega . \mathrm{cm}$. Sapphire substrates A-Plane (11-20) polished on the front side were also used for additional ellipsometry measurements. Prior to deposition, the wafers were cleaned using standard chemical process (Piranha $\left[\mathrm{H}_{2} \mathrm{O}_{2}, \mathrm{H}_{2} \mathrm{SO}_{4}\right]$ and diluted HF). $\mathrm{Al}_{2} \mathrm{O}_{3}$ films were deposited by ALD in an Ultratech Fiji F200 reactor. Trimethylaluminium (Al $\left.\left(\mathrm{CH}_{3}\right)_{3}\right)$ and water $\left(\mathrm{H}_{2} \mathrm{O}\right)$ were used as reactants. The chuck and chamber temperature was set to $250^{\circ} \mathrm{C}$ during deposition. Substrates were positioned on quartz holders to coat both surfaces in the same run. This was particularly interesting for minority carrier lifetime measurements that required passivation on both surfaces. For the present study the number of cycles was 
varied between 20 and 1000, leading to film thicknesses between 2 and $100 \mathrm{~nm}$. More precisely, we measured previously a growth per cycle (GPC) of $0.098 \mathrm{~nm}$ per cycle at $250^{\circ} \mathrm{C}$ on Si substrates [8]. After as-deposited characterizations, the samples were annealed in the ALD chamber in direct contact with the chuck. A range of temperatures $\left(350-450^{\circ} \mathrm{C}\right)$ and annealing times (5-15 min) were applied. The argon pressure was kept at around $670 \mathrm{~Pa}$. The annealing step is essential for photovoltaic applications to activate the surface charges and improve the surface passivation.

\section{Results and discussion}

In order to investigate the interface properties, different optical models were considered. These models account for an abrupt transition between the Si substrate and $\mathrm{Al}_{2} \mathrm{O}_{3}$ (Model 1), surface roughness (Model 2) or a $\mathrm{SiO}_{\mathrm{x}}$ interface layer (Model 3) at the $\mathrm{Si} / \mathrm{Al}_{2} \mathrm{O}_{3}$ interface, and a carbon surface layer due to surface contamination (Model 4). Negligible surface roughness at the interface $\mathrm{Al}_{2} \mathrm{O}_{3}$ /air was evidenced by atomic force microscope [8] and was therefore not included in the models.

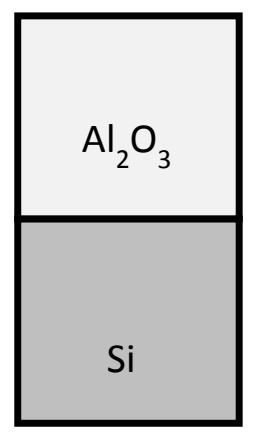

Model 1

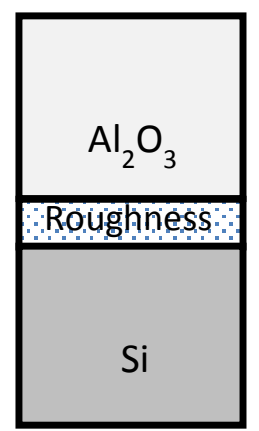

Model 2

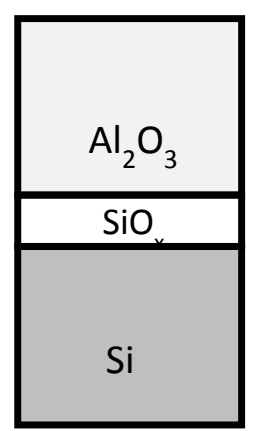

Model 3

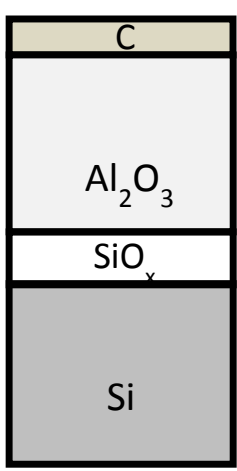

Model 4

Fig. 1. Optical models for $\mathrm{Al}_{2} \mathrm{O}_{3}$ layers deposited on $\mathrm{Si}$ substrates by thermal-ALD.

\subsection{Characterization of $\mathrm{Al}_{2} \mathrm{O}_{3}$ thin films by ellipsometry}

The thickness and wavelength-dependent refractive index $\mathrm{n}(\lambda)$ of the $\mathrm{Al}_{2} \mathrm{O}_{3}$ coatings were deduced from spectroscopic ellipsometry measurements in the $1.5-5 \mathrm{eV}$ range, using a Jobin Yvon Horiba apparatus. The incident angle relative to the surface was $20^{\circ}$. The $\mathrm{Al}_{2} \mathrm{O}_{3}$ layer thickness was extracted from the data analysis and compared with the value expected from the GPC. The refractive index of the layers was calculated using a simplified Sellmeier formula for transparent media (Eq. 1) that is supposed to be more accurate than Cauchy dispersion law for characterizing a material across a wide spectral range. The $\mathrm{B}$ and $\lambda_{1}$ parameters were fixed for the analysis at the following values: $\mathrm{B}=1.32$ and $\lambda_{1}=121.59 \mathrm{~nm}$, according to Kumar et al. [9]. 


$$
n(\lambda)=\sqrt{A+\frac{B \lambda^{2}}{\lambda^{2}-\lambda_{1}^{2}}}
$$

Refractive indexes calculated with the most relevant models and for different film thicknesses are plotted in Fig. 2. All refractive index values are given for a wavelength of $630 \mathrm{~nm}$. The fitted parameters are reported in Table 1 that gives the film thicknesses (e), refractive indexes (n), the Sellmeier coefficient A and the mean square error (MSE) to indicate the fit quality (a smaller value indicates a better fit to the experimental data).

\begin{tabular}{|c|c|c|c|c|c|c|c|}
\hline \multicolumn{2}{|c|}{ Number of ALD cycles } & 30 & 50 & 100 & 150 & 500 & 1000 \\
\hline \multicolumn{2}{|c|}{ Thickness from GPC (nm) } & 2.9 & 4.9 & 9.8 & 14.7 & 49 & 98 \\
\hline \multirow[t]{4}{*}{ Model 1} & $\mathrm{e}\left(\mathrm{Al}_{2} \mathrm{O}_{3}\right)$ & 3.9 & 5.5 & 10.6 & 15.8 & 50.9 & 101.2 \\
\hline & $\mathrm{n}$ & 2.15 & 2 & 1.84 & 1.76 & 1.66 & 1.65 \\
\hline & A & 3.25 & 2.65 & 2.01 & 1.8 & 1.37 & 1.37 \\
\hline & MSE & 2.76 & 2.84 & 2.58 & 1.67 & 4.14 & 8.81 \\
\hline \multirow[t]{5}{*}{ Model 3} & $\mathrm{e}\left(\mathrm{Al}_{2} \mathrm{O}_{3}\right)$ & 3.4 & 5.2 & 10.8 & 15.8 & 50.4 & 100 \\
\hline & $\mathrm{e}\left(\mathrm{SiO}_{\mathrm{x}}\right)$ & 0.8 & 0.8 & 0.8 & 0.8 & 1.2 & 1.2 \\
\hline & $\mathrm{n}$ & 1.74 & 1.7 & 1.66 & 1.66 & 1.65 & 1.65 \\
\hline & $\mathrm{A}$ & 1.66 & 1.54 & 1.4 & 1.41 & 1.38 & 1.38 \\
\hline & MSE & 2.6 & 2.14 & 2.3 & 1.11 & 4.19 & 5.15 \\
\hline
\end{tabular}

Table 1. Fitted parameters from ellipsometry measurements using Model 1 and Model 3: thickness (e), refractive index at $630 \mathrm{~nm}(\mathrm{n})$, A parameter from Sellmeier law and fit quality (MSE).

First, a simple optical model was assumed with an abrupt transition between the $\mathrm{Al}_{2} \mathrm{O}_{3}$ layer and the Si substrate (Model 1 in Fig. 1). In this case, the refractive index of $\mathrm{Al}_{2} \mathrm{O}_{3}$ was found to depend strongly on the film thickness as shown in Fig.2 (black hollow squares). A significant increase of the refractive index with decreasing thickness was observed below 50 $\mathrm{nm}(\mathrm{n}=1.65$ for a $50 \mathrm{~nm}$-thick film and $\mathrm{n}=2.15$ for a $3.9 \mathrm{~nm}$-thick film). Furthermore the fit accuracy decreased for thicknesses below $15 \mathrm{~nm}$. Above $50 \mathrm{~nm}$, the extracted value of the refractive index $(n=1.65)$ was constant and in agreement with the literature [1]. From these results it was assumed that the simple optical model (Model 1) was not suitable for thin films below $50 \mathrm{~nm}$ and that the contribution of interfaces had to be taken into account.

As proposed by Petrik et al. [10], roughness at the $\mathrm{Si} / \mathrm{Al}_{2} \mathrm{O}_{3}$ interface was taken into account in the ellipsometry data analysis. An interface layer was introduced as a Bruggeman effective medium composed of $50 \% \mathrm{Si}$ substrate and $50 \% \mathrm{Al}_{2} \mathrm{O}_{3}$ layer (Model 2) to simulate the surface roughness. Calculations lead to a negligible interface roughness of only $0.02 \mathrm{~nm}$ thickness and higher MSE values. Consequently, in our case, interface roughness does not explain the high refractive index values calculated for small $\mathrm{Al}_{2} \mathrm{O}_{3}$ thicknesses. Thermal ALD process leads to 
more conformal deposition than plasma enhanced-ALD that was used by Petrik et al. That may explain the rougher interfaces observed in their case.

The presence of a $\mathrm{Si}$-rich oxide layer with $\mathrm{Si}-\mathrm{Si}$ and $\mathrm{Si}-\mathrm{O}$ bonds has been reported in the literature to explain the refractive index measurements of very thin oxide film grown on $\mathrm{Si}$ substrates [11-13]. A Si-rich oxide layer $\left(\mathrm{SiO}_{\mathrm{x}}, \mathrm{x}<2\right)$ was introduced in our optical model at the interface between the $\mathrm{Si}$ substrate and the $\mathrm{Al}_{2} \mathrm{O}_{3}$ layer (Model 3 in Fig. 1). The refractive index of $\mathrm{SiO}_{\mathrm{x}}$ is expected to be intermediate between crystalline $\mathrm{Si}(\mathrm{n} \sim 3.87)$ and $\mathrm{SiO}_{2}(\mathrm{n} \sim$ 1.46). The best fits for the whole data range were obtained when introducing a $\mathrm{SiO}_{\mathrm{x}}$ layer of thickness close to $1 \mathrm{~nm}$ with a refractive index of 3.17. The new values of $\mathrm{Al}_{2} \mathrm{O}_{3}$ refractive index extracted with Model 3 are shown in Fig.2 (full red circles) as a function of thickness. Clearly the introduction of a $\mathrm{SiO}_{\mathrm{x}}$ layer at the $\mathrm{Si} / \mathrm{Al}_{2} \mathrm{O}_{3}$ interface reduces the calculated value of $\mathrm{Al}_{2} \mathrm{O}_{3}$ refractive index which is now close to the expected value of 1.66 for film thicker than $10 \mathrm{~nm}$, in agreement with the literature [1]. Table 1 summarizes the results obtained with Model 1 and Model 3. Note that although the fit accuracy is improved by the introduction of the sub-oxide interface for thin film, MSE increases for thicker $\mathrm{Al}_{2} \mathrm{O}_{3}$ layers (500 and 1000 cycles). This phenomenon was already described by Petrik et al. [10] and may indicate a slight inhomogeneity in thickness or refractive index or other non-ideality of the layer that are not taken into account by these models. Based on ellipsometry studies of the $\mathrm{Si} / \mathrm{SiO}_{2}$ interfaces $[12,14]$ and on the high value of the extracted refractive index (3.17), the composition of the $\mathrm{SiO}_{\mathrm{x}}$ interface layer could be roughly estimated to $\mathrm{x}<0.4$.

However, even with a $\mathrm{SiO}_{\mathrm{x}}$ interface layer, an increase of the extracted $\mathrm{Al}_{2} \mathrm{O}_{3}$ refractive index is observed for thickness below $10 \mathrm{~nm}$. This effect is attributed to the larger influence of the interface for very thin films and the strong correlation between the refractive index and thickness in the optical models and measurements [7, 10].

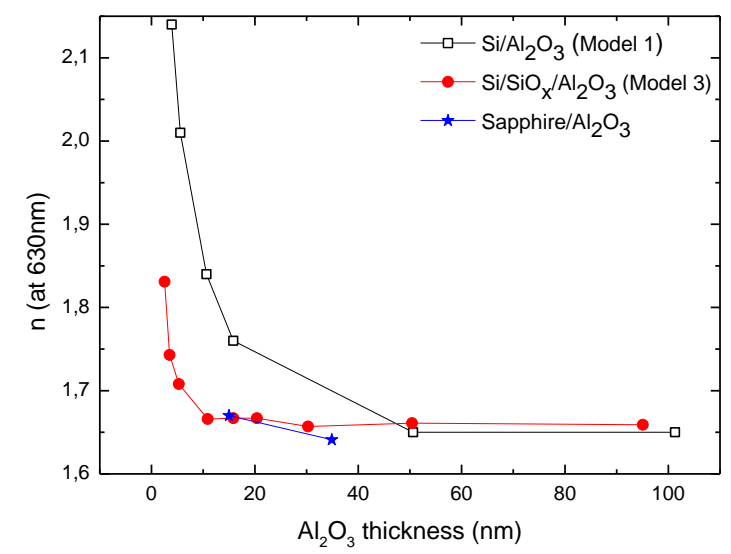

Fig.2. Refractive index of $\mathrm{Al}_{2} \mathrm{O}_{3}$ deposited on $\mathrm{Si}$ and sapphire substrates as a function of the film thickness. Ellipsometry data were fitted without $\mathrm{SiO}_{\mathrm{x}}$ interface layer (black hollow squares and blue stars) and with $\mathrm{SiO}_{\mathrm{x}}$ interface (full red dots).

To confirm the influence of an interface layer between $\mathrm{Si}$ and $\mathrm{Al}_{2} \mathrm{O}_{3}$ on the refractive index values, ellipsometry measurements were performed on $\mathrm{Al}_{2} \mathrm{O}_{3}$ layers deposited on sapphire substrates where the presence of $\mathrm{SiO}_{\mathrm{x}}$ is excluded. In this case, data were analyzed with a simple optical model sapphire/ $\mathrm{Al}_{2} \mathrm{O}_{3}$. As shown in Fig.2, the refractive index of a $15 \mathrm{~nm}$-thick 
$\mathrm{Al}_{2} \mathrm{O}_{3}$ was 1.67 . This result is in very good agreement with results obtained using Model 3 and tends to confirm the existence of the $\mathrm{SiO}_{\mathrm{x}}$ interface layer at the interface $\mathrm{Si}_{1} / \mathrm{Al}_{2} \mathrm{O}_{3}$.

A final hypothesis, taking into account both a SiOx interface layer and a possible surface hydro-carbon contamination (Model 4) was also investigated. The calculated thickness of the C-layer was close to zero $(0.001 \mathrm{~nm})$. Therefore, surface contamination does not have a significant influence on ellipsometry measurements.

In summary, our ellipsometry results do not seem compatible with an abrupt transition between the $\mathrm{Si}$ substrate and $\mathrm{Al}_{2} \mathrm{O}_{3}$ or with interface roughness. The best-fit model of ellipsometry data was obtained with a $\mathrm{SiO}_{\mathrm{x}}$ layer at the $\mathrm{Si} / \mathrm{Al}_{2} \mathrm{O}_{3}$ interface of thickness around $1 \mathrm{~nm}$ and refractive index around 3.17 at $630 \mathrm{~nm}$. This buried oxide layer is probably introduced via cleaning prior to deposition as $\mathrm{HF}$ etching leads to a Si-O-H surface which can be transformed into $\mathrm{SiO}_{\mathrm{x}}$ during the very first stages of the ALD process [10].

Fig. 3 compares the dispersion of the refractive index for a $10 \mathrm{~nm}$ thick $\mathrm{Al}_{2} \mathrm{O}_{3}$ layer extracted with Model 3 and the dispersion curve from Ref [9]. Our refractive index values appear slightly over estimated by roughly $1 \%$ compared to Kumar's dispersion curve. This might be explained by the strong dependence of thin film properties on cleaning procedure and deposition conditions.

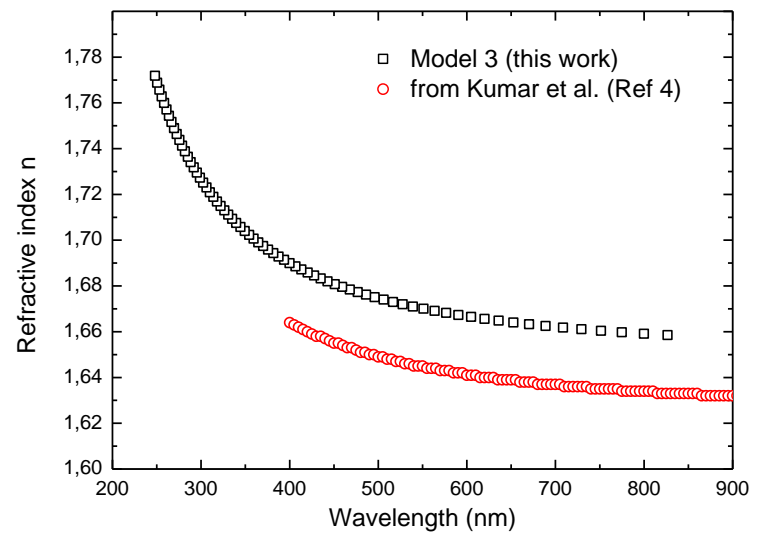

Fig. 3. Refractive index as a function of wavelength for a $10 \mathrm{~nm} \mathrm{Al}_{2} \mathrm{O}_{3}$ layer (hollow black squares) as well as the dispersion from Ref [9] (red full circles).

\subsection{Characterization of $\mathrm{Al}_{2} \mathrm{O}_{3}$ thin films by $\mathrm{X}$-ray reflectivity}

X-Ray Reflectivity (XRR) measurements were used to confirm the presence of a $\mathrm{SiO}_{\mathrm{x}}$ interface layer and to evaluate its thickness. This method is fairly simple, rapid and nondestructive and provides also information on the density, surface and interface roughness. We used a Rigaku Smartlab diffractometer equipped with a $9 \mathrm{~kW}$ rotating anode and high resolution optics (two bounces Ge 220 monochromator and narrow aperture slits) placed on the incident beam. Measurements were made on $\mathrm{Al}_{2} \mathrm{O}_{3}$ layers deposited with 30 to 200 thermal ALD cycles. XRR analysis was performed with low incidence angles relative to the surface $\left(0-7^{\circ}\right)$. Consequently results were influenced by surface contamination (contrary to 
the ellipsometry, where a $20^{\circ}$ angle relative to the surface was used). For this reason data were also analyzed with a model that takes into account a carbon surface layer in Fig.1.

Examples of measurements performed on very thin films (30 to 100 cycles) are shown in Fig. 4. The reflectivity profile showed oscillations caused by interference between the X-rays reflected at the different interfaces. Since these oscillations were used to calculate the thickness of the layers, it appeared that the minimum measurable film thickness was about 3 $\mathrm{nm}$ for $\mathrm{Al}_{2} \mathrm{O}_{3}$ on $\mathrm{Si}$, when oscillations are still visible. Model $3\left(\mathrm{Si} / \mathrm{SiO}_{\mathrm{x}} / \mathrm{Al}_{2} \mathrm{O}_{3}\right)$ was used to fit the data in Fig.4.

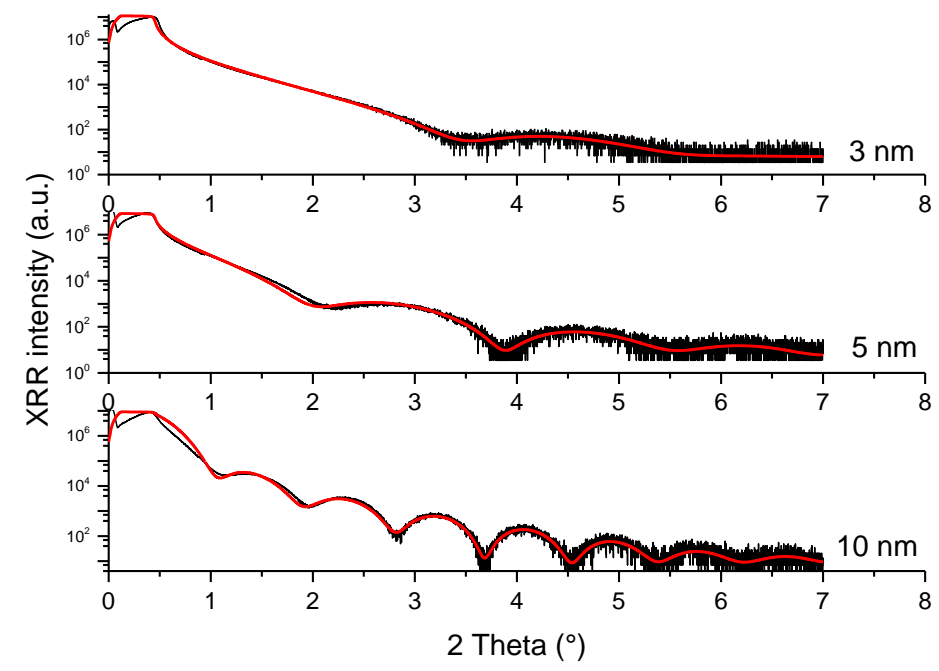

Fig. 4. XRR data (black) and fitted curve (red) for different $\mathrm{Al}_{2} \mathrm{O}_{3}$ thicknesses.

Data analyses using the different models introduced for ellipsometry were compared. Fig. 5 shows on an enlarged scale the theoretical and fitted curves obtained with Model 1, 3 and 4 for a 150 cycles film. It is quite clear from Fig.5 (left) that Model 3 ( $\mathrm{SiO}_{\mathrm{x}}$ interface) lead to a closer fit than Model 1 (abrupt $\mathrm{Si} / \mathrm{Al}_{2} \mathrm{O}_{3}$ ). On the other hand, the introduction of a C-layer at the interface Si/air (Model 4) did not provide a significant improvement on the fitting accuracy as compared to Model 3 (Fig.5 right).
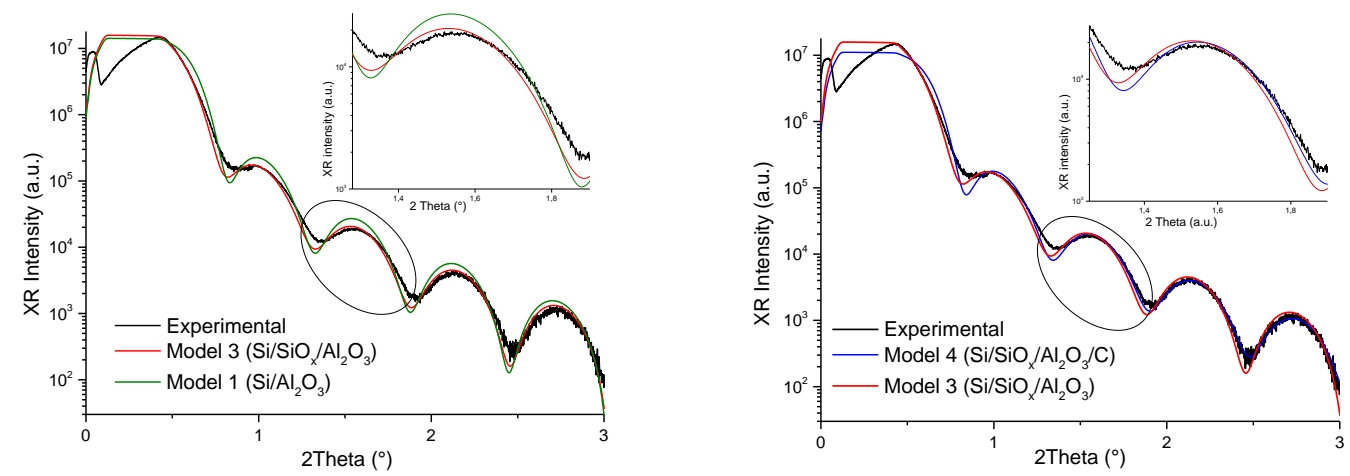
Fig. 5. Examples of experimental (black) and fitted curves for 150 cycles of $\mathrm{Al}_{2} \mathrm{O}_{3}$ on $\mathrm{Si}$. Left: comparison between Model 1 (green) and Model 3 (red). Right: comparison between Model 3 (red) and Model 4 (blue). The inserts detail one oscillation.

The thickness (e) of the layers and the fit quality (S) when Model 1, 3 and 4 were used to analyze the XRR data are reported in Table 2. The introduction of a $\mathrm{SiO}_{\mathrm{x}}$ interface improved the fit quality ( $\mathrm{S}$ decreased). The thickness of the $\mathrm{SiO}_{\mathrm{x}}$ interface layer determined by XRR was between 0.9 and $1.3 \mathrm{~nm}$, comparable to values obtained by ellipsometry ( 0.8 to $1.2 \mathrm{~nm})$. A carbon surface layer (Model 4) improved the fit quality only for films thicker than 150 cycles. However, the $\mathrm{Al}_{2} \mathrm{O}_{3}$ thicknesses obtained with Model 4 are noticeably different from the thickness calculated from the GPC (from $4 \%$ deviation for 200 cycles to $21 \%$ for 30 cycles). Note that as for the ellipsometry measurements, the fit quality decreases for increasing $\mathrm{Al}_{2} \mathrm{O}_{3}$ thickness for Model 1 and 3 .

\begin{tabular}{llccccc}
\hline Number of & $\mathrm{ALD}$ cycles & 30 & 50 & 100 & 150 & 200 \\
\cline { 2 - 7 } Thickness from $\mathrm{GPC}(\mathrm{nm})$ & 2.94 & 4.9 & 9.8 & 14.7 & 19.6 \\
\cline { 2 - 6 } Model 1 & $\mathrm{e}\left(\mathrm{Al}_{2} \mathrm{O}_{3}\right)$ & 2.6 & 4.6 & 9.7 & 14.8 & 19.7 \\
& $\mathrm{~S}$ & 0.26 & 0.31 & 0.38 & 0.68 & 0.61 \\
\hline \multirow{2}{*}{ Model 3 } & $\mathrm{e}\left(\mathrm{Al}_{2} \mathrm{O}_{3}\right)$ & 2.6 & 4.6 & 9.7 & 14.8 & 19.6 \\
& $\mathrm{e}\left(\mathrm{SiO}_{\mathrm{x}}\right)$ & 1.2 & 1.2 & 1.1 & 0.9 & 1.3 \\
& $\mathrm{~S}$ & 0.23 & 0.28 & 0.33 & 0.54 & 0.5 \\
\hline \multirow{2}{*}{ Model 4 } & $\mathrm{e}(\mathrm{C})$ & 0.7 & 0.7 & 0.6 & 0.9 & 0.9 \\
& $\mathrm{e}\left(\mathrm{Al}_{2} \mathrm{O}_{3}\right)$ & 2.3 & 4.1 & 9.3 & 13.9 & 18.8 \\
& $\mathrm{e}\left(\mathrm{SiO}_{\mathrm{x}}\right)$ & 1.2 & 1.2 & 1.2 & 1.3 & 1.4 \\
& $\mathrm{~S}$ & 0.22 & 0.28 & 0.31 & 0.25 & 0.3 \\
\hline
\end{tabular}

Table 2. Calculated thickness (e) from XRR measurements using Model $1\left(\mathrm{Al}_{2} \mathrm{O}_{3} / \mathrm{Si}\right)$, Model

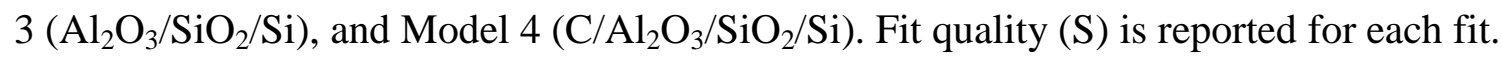

Table 3 compares the $\mathrm{Al}_{2} \mathrm{O}_{3}$ thicknesses calculated from ellipsometry and XRR data using Model 3 that seemed the best suited to analyze our experimental data. The differences between the expected thickness calculated from the GPC and the measured thickness vary between 1 and $12 \%$ for XRR measurements and 6 to $16 \%$ for ellipsometry measurements. These values give an order of magnitude of the uncertainty when investigating very thin layers.

\begin{tabular}{lcccc}
\cline { 2 - 5 } Number of ALD cycles & 30 & 50 & 100 & 150 \\
\hline Thickness from GPC $(\mathrm{nm})$ & 2.94 & 4.9 & 9.8 & 14.7 \\
\hline Thickness from XRR & 2.6 & 4.6 & 9.7 & 14.8 \\
Thickness from Ellipsometry & 3.4 & 5.2 & 10.8 & 15.8 \\
\hline
\end{tabular}

Table 3. Comparison between $\mathrm{Al}_{2} \mathrm{O}_{3}$ thicknesses extracted from XRR and ellipsometry data using Model 3. 
The density of the $\mathrm{SiO}_{\mathrm{x}}$ interface layer given by XRR data analysis was $2.29 \mathrm{~g} . \mathrm{cm}^{-3}$. As the density of $\mathrm{SiO}_{2}$ and $\mathrm{Si}$ are $2.2 \mathrm{~g} . \mathrm{cm}^{-3}$ and $2.33 \mathrm{~g} . \mathrm{cm}^{-3}$ respectively, $\mathrm{x}$ can be estimated to be $<0.5$ assuming a linear variation of the density with composition. This value is in agreement with our previous estimation of $\mathrm{x}<0.4$ obtained by ellipsometry. From XRR data, the calculated density of the $\mathrm{Al}_{2} \mathrm{O}_{3}$ layer deposited at $250^{\circ} \mathrm{C}$ was $3.2 \mathrm{~g} / \mathrm{cm}^{3}$. This value is in agreement with the density of $3.15 \mathrm{~g} / \mathrm{cm}^{3}$ reported by Triani [15] for a deposition temperature of $200^{\circ} \mathrm{C}$. Indeed, the density of ALD films decreases at lower deposition temperatures as noted by Groner [16], who reported a density of $3 \mathrm{~g} / \mathrm{cm} 3$ for a deposition temperature of $177^{\circ} \mathrm{C}$. More generally, the densities of thin $\mathrm{Al}_{2} \mathrm{O}_{3}$ films deposited by ALD are significantly smaller than the reported values of $3.75-3.95 \mathrm{~g} / \mathrm{cm}^{3}$ for bulk alumina [17].

\subsection{Chemical composition of $\mathrm{Al}_{2} \mathrm{O}_{3}$ thin films}

Chemical composition was measured by X-Ray Photoelectron Spectroscopy (XPS) and by Electron Probe Micro-Analysis (EPMA) on as-deposited $\mathrm{Al}_{2} \mathrm{O}_{3}$ layers of different thicknesses to investigate the material composition and the interface structure. XPS measurements were carried out in a Vacuum Science Workshop chamber equipped with a monochromatic X-ray source Al K-alpha (1486.6eV). The angle between the X-ray source and the photoelectron detector was $54.7^{\circ}$. EPMA was performed with a CAMECA SX50 equipped with four vertical wavelength dispersive spectrometers.

Although the $\mathrm{O} / \mathrm{Al}$ ratio was close to the expected value of 1.5 for thick samples, an increase of this ratio (up to 1.87) with decreasing $\mathrm{Al}_{2} \mathrm{O}_{3}$ thickness was observed with both techniques (Table.4). This augmentation was attributed to the $\mathrm{SiO}_{\mathrm{x}}$ interface layer whose contribution to the O-concentration was more important for thin $(<10 \mathrm{~nm}) \mathrm{Al}_{2} \mathrm{O}_{3}$ layers.

\begin{tabular}{|c|c|c|}
\hline $\begin{array}{c}\mathrm{Al}_{2} \mathrm{O}_{3} \text { thickness } \\
(\mathrm{nm})\end{array}$ & $\begin{array}{l}\mathrm{O} / \mathrm{Al} \\
\text { (XPS) }\end{array}$ & $\begin{array}{c}\mathrm{O} / \mathrm{Al} \\
\text { (EPMA) }\end{array}$ \\
\hline 4.9 & 1.87 & 1.86 \\
\hline 9.8 & 1.86 & 1.76 \\
\hline 14.7 & 1.70 & - \\
\hline 19.6 & - & 1.61 \\
\hline 98 & - & 1.55 \\
\hline
\end{tabular}

Table 4. O/Al ratio measured by XPS and EPMA for as-deposited $\mathrm{Al}_{2} \mathrm{O}_{3}$ layers.

In this section, refractive index, density and composition of as-deposited $\mathrm{Al}_{2} \mathrm{O}_{3}$ films were investigated. Experimental data were compatible with the presence of a Si-rich $\mathrm{SiO}_{\mathrm{x}}(\mathrm{x}<0.4-$ 0.5 ) interface layer between $\mathrm{Al}_{2} \mathrm{O}_{3}$ and the Si substrate of thickness around $1 \mathrm{~nm}$. 


\subsection{Effect of thermal annealing on the properties of the $\mathrm{Al}_{2} \mathrm{O}_{3}$ thin films}

The application of the $\mathrm{Al}_{2} \mathrm{O}_{3}$ layers to surface passivation of $\mathrm{Si}$ solar cells requires further processing and characterization. As-deposited $\mathrm{Al}_{2} \mathrm{O}_{3}$ layers grown by thermal-ALD provide already a significant level of surface passivation of Si substrates mainly due to the reduction of the electrically active interface states (dangling bonds) by chemical bonding. However, further reduction of the surface recombination requires the activation of charges at the $\mathrm{Al}_{2} \mathrm{O}_{3} / \mathrm{Si}$ interface that provide a field-effect passivation. Negative charges are activated by thermal annealing. This section describes the optimization of the annealing process, the surface recombination velocity measurements and the effect of the thermal treatment on the material and interfaces parameters discussed in section 3.1 to 3.3.

The impact of surface recombination on solar cell efficiency can be evaluated by measuring the minority carrier lifetime $\left(\tau_{\text {eff }}\right)$. The effective lifetime can be expressed as a bulk lifetime $\left(\tau_{\text {bulk }}\right)$ and a surface lifetime $\left(\tau_{\text {surface }}\right)$ contribution [18]:

$$
\frac{1}{\tau_{\text {eff }}}=\frac{1}{\tau_{\text {bulk }}}+\frac{1}{\tau_{\text {suface }}}
$$

For a symmetrically passivated wafer with sufficiently low surface defect density, Eq. 1 can be expressed as:

$$
\frac{1}{\tau_{\text {eff }}}=\frac{1}{\tau_{\text {bulk }}}+\frac{2 S}{e}
$$

$\mathrm{S}$ is the surface recombination velocity and $\mathrm{e}$ is the wafer thickness [18]. For the high resistivity $\mathrm{Si}$ substrates used in this study with bulk lifetimes larger than $10 \mathrm{~ms}, \mathrm{~S}$ can be directly related to $\tau_{\text {eff }}$ by $S=e / 2 \tau_{\text {eff }}$.

The minority carrier lifetime was evaluated by Photo-Conductance Decay using a Sinton Instruments WCT-120 system [19]. This parameter was first measured on as-deposited n-type Si substrates coated on both sides with $\mathrm{Al}_{2} \mathrm{O}_{3}$ layers of various thicknesses (from 5 to $50 \mathrm{~nm}$ ). The surface passivation increased for $\mathrm{Al}_{2} \mathrm{O}_{3}$ layers between 5 and $15 \mathrm{~nm}$ and tended to stabilize for larger thicknesses. For an injection level of $2.10^{14} \mathrm{~cm}^{-3}, \tau_{\text {eff }}$ was $1.2 \mathrm{~ms}$ for $5 \mathrm{~nm}$ of $\mathrm{Al}_{2} \mathrm{O}_{3}$ and $2 \mathrm{~ms}$ for $15 \mathrm{~nm}$. The augmentation of $\tau_{\text {eff }}$ for as-deposited thicker films was related to the deposition time and attributed to an in situ annealing effect taking place in the ALD reactor during deposition at $250^{\circ} \mathrm{C}$ [1].

After $\tau_{\text {eff }}$ measurements on as-deposited samples, annealing was done on the samples coated with $15 \mathrm{~nm}$ of $\mathrm{Al}_{2} \mathrm{O}_{3}$. The Ar pressure was kept constant to $670 \mathrm{~Pa}$. Temperature was varied between $350^{\circ} \mathrm{C}$ and $450^{\circ} \mathrm{C}$ and annealing time was varied between $5 \mathrm{~min}$ and $15 \mathrm{~min}$. As reported previously, maximum $\tau_{\text {eff }}$ values around $5.8 \mathrm{~ms}$ were measured after annealing at $400^{\circ} \mathrm{C}$ for $10 \mathrm{~min}$ [8]. From the maximum $\tau_{\text {eff }}$ value of $5.8 \mathrm{~ms}$, the surface recombination velocity was estimated to $\mathrm{S}$ around $2.4 \mathrm{~cm} / \mathrm{s}$. This result is in good agreement with the very low surface recombination velocities $\mathrm{S}<5 \mathrm{~cm} / \mathrm{s}$ reported in the literature [1]. 
Once the annealing step was optimized in order to obtain the lowest surface recombination velocity, the effect of the thermal treatment $\left(400^{\circ} \mathrm{C}\right.$ for $\left.10 \mathrm{~min}\right)$ on the material and interfaces parameters determined in the previous section was evaluated by ellipsometry, XRR and XPS measurements. Ellipsometry measurements after the annealing step revealed a slight increase (less than $3 \%$ ) of the refractive index with the assumption that the thickness of $\mathrm{Al}_{2} \mathrm{O}_{3}$ did not change with temperature. This could indicate an increase of density of $\mathrm{Al}_{2} \mathrm{O}_{3}$ after thermal treatment. From XRR measurements the density of alumina layers was found to increase by $4 \%$ after annealing, rising from $3.2 \mathrm{~g} / \mathrm{cm}^{3}$ to $3.33 \mathrm{~g} / \mathrm{cm}^{3}$ in agreement with XRR observation. The $\mathrm{SiO}_{\mathrm{x}}$ interface layer maintained the same thickness after annealing but its density decreased by about $1 \%$. This could indicate an increase of the oxygen content in the interface buried layer. An increase of the O/Al ratio was observed from XPS measurements after annealing. As the effect was more pronounced on $5 \mathrm{~nm}$-thick film, it could be assumed that the interface evolved with annealing. The increase of oxygen concentration at the interface could correspond to an increase of the thickness or/and an increase of the oxygen content in the interface layer.

\begin{tabular}{ccc}
$\begin{array}{c}\mathrm{Al}_{2} \mathrm{O}_{3} \text { thickness } \\
(\mathrm{nm})\end{array}$ & $\begin{array}{c}\mathrm{O} / \mathrm{Al} \\
\text { as-deposited }\end{array}$ & $\begin{array}{c}\mathrm{O} / \mathrm{Al} \\
\text { annealed }\end{array}$ \\
\hline 4.8 & 1.87 & 2.2 \\
14.7 & 1.70 & 1.83 \\
\hline
\end{tabular}

Table 5. $\mathrm{O} / \mathrm{Al}$ ratio measured by XPS for as-deposited and annealed (10 min at $\left.400^{\circ} \mathrm{C}\right) \mathrm{Al}_{2} \mathrm{O}_{3}$ layers.

Overall, the evolution of the $\mathrm{Al}_{2} \mathrm{O}_{3}$ layers and of the $\mathrm{Al}_{2} \mathrm{O}_{3} / \mathrm{Si}$ interfaces with the annealing step was small and within the error range of measurements. However some general trends of evolution could be noted. The $\mathrm{Al}_{2} \mathrm{O}_{3}$ density seemed to increase with annealing. Concerning the interface layer, the decrease of its density confirmed the increased oxygen content noted by XPS on annealed samples. The interface layer appeared to be richer in oxygen after annealing.

\section{Conclusion}

$\mathrm{Al}_{2} \mathrm{O}_{3}$ thin films with thickness between 2 and $100 \mathrm{~nm}$ were deposited at $250^{\circ} \mathrm{C}$ by thermal atomic layer deposition (ALD) on n-type FZ silicon substrates. Special emphasis was put on the characterization of very thin films $(<15 \mathrm{~nm})$ that are commonly used for surface passivation of $\mathrm{Si}$ solar cells. A $1 \mathrm{~nm}$-thick $\mathrm{Si}$-rich $\mathrm{SiO}_{\mathrm{x}}$ layer $(\mathrm{x}<0.4$ to 0.5$)$ at the interface between $\mathrm{Si}$ and $\mathrm{Al}_{2} \mathrm{O}_{3}$ was introduced in the optical models to explain the ellipsometry and XRR experimental data. Chemical composition was measured by X-Ray Photoelectron Spectroscopy (XPS) and linked with the interface structure. As-deposited $\mathrm{Al}_{2} \mathrm{O}_{3}$ layers resulted in a significant level of surface passivation of the Si substrates. However, further reduction of the surface recombination velocity down to $2.4 \mathrm{~cm} . \mathrm{s}^{-1}$ was observed after the 
activation of the negative charges at the $\mathrm{Si} / \mathrm{Al}_{2} \mathrm{O}_{3}$ interface under optimized annealing conditions $\left(400^{\circ} \mathrm{C}\right.$ for $\left.10 \mathrm{~min}\right)$. The stability of the $\mathrm{Al}_{2} \mathrm{O}_{3}$ layer after annealing was confirmed by ellipsometry, XRR and XPS although the $\mathrm{Al}_{2} \mathrm{O}_{3}$ density increased slightly and the $\mathrm{SiO}_{\mathrm{x}}$ interface layer appeared to be richer in oxygen after annealing.

\section{Acknowledgements}

Corina Barbos is grateful to Région Rhône-Alpes (ARC-4 Energies) for a supporting grant.

\section{References}

[1] G. Dingemans, W.M. M. Kessels, Status and prospects of $\mathrm{Al}_{2} \mathrm{O}_{3}$-based surface passivation schemes for silicon solar cells, J. Vac. Sci. Technol. A30 (2012) 040802-1.

[2] S. W. Glunz, J. Benick, D. Biro, M. Bivour, M. Hermle, D. Pysch, M. Rauer. C. Reichel, A. Richter, M. Rudiger, C. Schmiga, D. Suwito, A. Wolf, R. Preu, n-Type Silicon- enabling efficiencies $>20 \%$ in industrial production, 35th IEEE Conf. Proc. (2010) 50-56.

[3] J. Benick, B. Hoex, M.C.M. van de Sanden, W.M.M. Kessels, O. Schultz, S.W. Glunz, High efficiency n-type $\mathrm{Si}$ solar cells on $\mathrm{Al}_{2} \mathrm{O}_{3}$-passivated boron emitters, Appl. Phys. Lett. 92 (2008) 253504-1.

[4] P. Repo, H. Talvitie, S. Li, J. Skarp, H. Savin, Silicon surface passivation by $\mathrm{Al}_{2} \mathrm{O}_{3}$ : effect of ALD reactants, Energy Procedia 8 (2011) 681-687.

[5] B. Hoex, J. Shmidt, P. Pohl, M.C.M. van de Sanden, W.M.M Kessels, Silicon surface passivation by atomic layer deposited $\mathrm{Al}_{2} \mathrm{O}_{3}$, J. Appl. Phys. 104 (2008) 044903.

[6] International Technology Roadmap for Photovoltaics 2014 Results, $6^{\text {th }}$ ed. (2015).

[7] D. Chandler-Horowitz, N.V. Nguyen, J.R. Ehrstein, Assessment of ultra-thin $\mathrm{SiO}_{2}$ film thickness measurement precision by ellipsometry, AIP Conf. Proc. 683 (2003) 326-330.

[8] C. Barbos, D. Blanc-Pelissier, A. Fave, E. Blanquet, A. Crisci, E. Fourmond, D. Albertini, A. Sabac, K. Ayadi, M. Lemiti, Characterization of Al2O3 thin films prepared by ALD, Aceepted for publication in Energy Proceedia, 77 (2015) 558-564.

[9] P. Kumar, M.K. Wiedmann, C.H. Winter and I. Avrutsky, Optical properties of $\mathrm{Al}_{2} \mathrm{O}_{3}$ thin films grown by atomic layer deposition, Appl Opt. (2009) 5407-12.

[10] P. Petrik, T. Gumprecht, A. Nutsch , G. Roeder, M. Lemberger , G. Juhasz , O. Polgar , C. Major, P. Kozma , M. Janosov, B. Fodor, E. Agocs, M. Fried, Comparative measurements on atomic layer deposited $\mathrm{Al}_{2} \mathrm{O}_{3}$ thin films using ex situ table top and mapping ellipsometry, as well as X-ray and VUV reflectometry, Thin Solid Films 541 (2013) 131-135.

[11] H. Fujiwara, Spectroscopic ellipsometry: principles and applications, Wiley, West Sussex, U.K. 2007.

[12] D.E. Aspnes, J.B. Theeten, Optical properties of the interface between Si and its thermally grown oxide, Phys. Rev. Lett. 43 (1979) 1046-1050.

[13] E. Langereis, S.B.S. Heil, H.C.M. Knoops, W. Keuning, M.C.M. van de Sanden, W.M.M. Kessels, In situ spectroscopic ellipsometry as a versatile tool for studying atomic layer deposition, J. Appl. Phys. 42 (2009) 073001.

[14] N. Tomozeiu, Silicon Oxide (SiOx, $0<x<2$ ): a Challenging Material for Optoelectronics, in: P. Predeep (Ed.), Optoelectronics- Materials and techniques, InTech, 2011, pp. 55-98.

[15] G. Triani, P.J. Evans, D.R.G. Mitchell, D.J. Attard, K.S. Finnie, M. James, T. Hanley, B. Latella, K.E. Prince, J. Bartlett, Atomic layer deposition of $\mathrm{TiO}_{2} / \mathrm{Al}_{2} \mathrm{O}_{3}$ films for optical applications, in: Advances in Thin-Film Coatings for Optical Applications II, edited by Michael L. Fulton, Jennifer D. T. Kruschwitz, Proc. of SPIE Vol. 5870 (2005) 587009.

[16] M.D. Groner, F.H. Fabreguette, J.W. Elam, S.M.George, Low-temperature $\mathrm{Al}_{2} \mathrm{O}_{3}$ Atomic Layer Deposition, Chem. Mater. 16 (2004) 639-645. 
[17] D.R. Lide, CRC Handbook of Chemistry and Physics, 75th ed., CRC Press, Boca Raton, 1994.

[18] A.B. Sproul, Dimensionless solution of the equation describing the effect of surface recombination on carrier decay in semiconductors, J. Appl. Phys. 76 (1994) 2851-2854.

[19] R. A. Sinton, A. Cuevas, M. Stuckings, Quasi-steady-state photoconductance, a new method for solar cell material and device characterization, 25th IEEE Conf. Proc. (1996) 457-460. 